\title{
Accuracy and reliability of pulse oximetry at different arterial carbon dioxide
} pressure levels

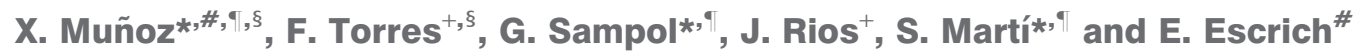

ABSTRACT: The present study aimed to assess whether arterial carbon dioxide pressure $\left(\mathrm{Pa}, \mathrm{CO}_{2}\right)$ has an impact on agreement between oxygen saturation measured with pulse oximetry $\left(\mathrm{Sp}_{\mathrm{p}} \mathrm{O}_{2}\right)$ or arterial blood gas co-oximetry $\left(\mathrm{Sa}, \mathrm{O}_{2}\right)$.

$\mathrm{Sa}, \mathrm{O}_{2}$ and $\mathrm{Sp}, \mathrm{O}_{2}$ determinations were obtained simultaneously from 846 patients under assessment for long-term home oxygen therapy in a specialised outpatient clinic. Both measurements were taken with patients seated and breathing room air.

Agreement between $\mathrm{Sa}, \mathrm{O}_{2}$ and $\mathrm{Sp}, \mathrm{O}_{2}$ results was analysed by the Bland-Altman method and the Lin concordance coefficient. In addition, potential interactions of arterial oxygen tension $\left(\mathrm{Pa}_{2} \mathrm{O}_{2}\right)$ or $\mathrm{Pa}, \mathrm{CO}_{2}$ on agreement were analysed by adjusted multivariate analysis.

Upon comparison of $\mathrm{Sa}, \mathrm{O}_{2}$ and $\mathrm{Sp}, \mathrm{O}_{2}$ results, the Bland-Altman technique yielded a bias $(95 \%$ confidence interval $(\mathrm{Cl})$ ) of $-1.24(-6.86-4.38)$ and $-1.32(-7.78-5.15)$ when $\mathrm{Pa}_{1} \mathrm{CO}_{2}>48 \mathrm{mmHg}$ (6.39 $\mathrm{kPa})$ or $\mathrm{Pa}, \mathrm{O}_{2}<54 \mathrm{mmHg}(7.20 \mathrm{kPa})$, respectively. Estimate by Lin's coefficient $(95 \% \mathrm{Cl})$ in these cases was $0.88(0.85-0.90)$ and $0.81(0.77-0.85)$. Adjusted multivariate analysis, performed to assess the impact of $\mathrm{pH}, \mathrm{Pa}, \mathrm{O}_{2}, \mathrm{~Pa}_{1} \mathrm{CO}_{2}$ and bicarbonate on bias, showed that $\mathrm{Pa}, \mathrm{O}_{2}, \mathrm{~Pa}_{1} \mathrm{CO}_{2}$ and their interaction terms were the most important predictors of the bias (standardised estimates of $-0.54,-0.94$, and 0.85 , respectively). The effect of $\mathrm{pH}$, although statistically significant, was small, and bicarbonate had no significant effect.

Arterial carbon dioxide pressure status can contribute to impaired agreement between arterial oxygen saturation and arterial oxygen saturation measured with pulse oximetry, particularly in patients with hypercapnia.

\section{KEYWORDS: Co-oximetry, hypercapnia, hypoxaemia, oxygen therapy, precision}

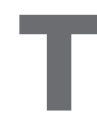

he use of pulse oximetry is one of the most important advances in respiratory monitoring and in the management of certain respiratory diseases [1]. Nevertheless, there may be discrepancies between oxygen saturation measured with pulse oximetry $\left(\mathrm{Sp}_{\mathrm{p}} \mathrm{O}_{2}\right)$ and the actual status as calculated from arterial blood gas cooximetry $\left(\mathrm{Sa}, \mathrm{O}_{2}\right) . \mathrm{Sp}, \mathrm{O}_{2}$ can be elevated relative to $\mathrm{Sa}_{1} \mathrm{O}_{2}$ when carboxyhaemoglobin levels are high, and in the presence of intravascular dyes, dark skin pigmentation, motion artefacts, nail polishes, optical shunting or poor peripheral perfusion [24]. In contrast, lower $\mathrm{Sp}_{\mathrm{p}} \mathrm{O}_{2}$ values can be produced when there is: an abnormal haemoglobin variant; methaemoglobinaemia; sulfhaemoglobinaemia; prominent venous pulsations; or contamination of measurement by ambient light, as well as intravenous dyes and nail polish [5].

Several studies have demonstrated that the majority of pulse oximetry readings correlate well with $\mathrm{Sa}_{2} \mathrm{O}_{2}$ when none of the aforementioned factors is present and $S p, O_{2}$ is $84-96 \%$ [6], and quite well when $S p, \mathrm{O}_{2}$ is $>70 \%$ [7]. Most of these studies have been done in hospitalised patients, generally in intensive care units, or in healthy individuals who are exposed to various conditions of hypoxia. Very few studies have examined the agreement between $\mathrm{Sa}_{1} \mathrm{O}_{2}$ and $\mathrm{Sp}, \mathrm{O}_{2}$ in the setting of outpatient monitoring [8-10], an area in which this information can be highly relevant. With the development of long-term home oxygen therapy and home mechanical ventilation, clinicians attend an increasingly greater number of patients with end-stage lung disease in whom the decisions regarding these and other therapies are often based on pulse oximetry findings [11-14].

Many patients with end-stage lung disease have chronic respiratory failure and present elevated arterial carbon dioxide pressure $\left(\mathrm{Pa}_{\mathrm{a}} \mathrm{CO}_{2}\right)$ [15]. Currently, there are no studies that determine

\section{AFFILIATIONS}

*Servei de Pneumologia, Hospital Universitari Vall d'Hebron, \#Dept de Biología Cellular, de Fisiologia i d'Immunologia, UAB, +Laboratorio de Bioestadística i Epidemiología (Universitat Autònoma de Barcelona); Servei de Farmacologia Clínica, IDIBAPS, (Hospital Clínic), Barcelona, and "CIBER de Enfermedades Respiratorias (Ciberes), Spain. ${ }^{\S}$ Both authors contributed equally to the study.

CORRESPONDENCE

$X$. Muñoz

Servei de Pneumologia Hospital Vall d'Hebron

$\mathrm{P}^{\circ}$ Vall d'Hebron

119-129

08035 Barcelona

Spain

Fax: 34932746083

E-mail: xmunoz@vhebron.net

Received:

September 252007

Accepted after revision:

April 292008

STATEMENT OF INTEREST

None declared. 
whether blood $\mathrm{CO}_{2}$ alterations can result in discrepancies between $\mathrm{Sa}_{1} \mathrm{O}_{2}$ and $\mathrm{Sp}, \mathrm{O}_{2}$ results and very few have analysed agreement between $\mathrm{Sa}_{1} \mathrm{O}_{2}$ and $\mathrm{Sp}, \mathrm{O}_{2}$ in patients with $\mathrm{Sp}_{\mathrm{p}} \mathrm{O}_{-}$ $<70 \%$ [16], a frequent situation in this population [11-13]. The main aim of the present study was to determine whether altered blood $\mathrm{CO}_{2}$ levels can change the existing relationship between $\mathrm{Sa}_{1} \mathrm{O}_{2}$ and $\mathrm{Sp}, \mathrm{O}_{2}$. In addition, it was assessed whether $\mathrm{Sp}, \mathrm{O}_{2}$ could provide a valid estimate of $\mathrm{Sa}_{1} \mathrm{O}_{2}$ at very low levels of hypoxaemia in a large number of samples from patients with various respiratory diseases.

\section{MATERIAL AND METHODS \\ Materials}

The present study was performed from $\mathrm{Sa}, \mathrm{O}_{2}$ and $\mathrm{Sp}, \mathrm{O}_{2}$ determinations obtained simultaneously from 846 patients under assessment for long-term home oxygen therapy in a specialised outpatient centre. The population included all patients who underwent arterial blood gas measurement and $\mathrm{Sp}, \mathrm{O}_{2}$ determination between January 1995 and December 2004. A total of 216 patients were excluded for the following reasons: one of the two determinations could not be performed; the patient presented factors that could result in false $\mathrm{Sa}_{2} \mathrm{O}_{2}$ or $\mathrm{Sp}, \mathrm{O}_{2}$ results (e.g. active smoking at the time of the determination, carboxyhaemoglobin levels $>2 \%$, abnormal haemoglobin variants, presence of i.v. dyes, use of blue nail polish or prominent venous pulsations); or $\mathrm{Sp}, \mathrm{O}_{2}$ changes were observed during puncture for blood gas measurement.

The characteristics of the patients studied are summarised in table 1. All were Caucasian and none had scleroderma or Raynaud phenomenon. Among the total, 570 (67.4\%) patients were receiving oxygen at home at the time they were assessed.

\section{Methods}

Measurement of arterial oxygen saturation by co-oximetry Room air arterial blood gas sampling was performed according to the Spanish Society of Pulmonology and Thoracic Surgery

\begin{tabular}{|c|c|c|}
\hline TABLE 1 & \multicolumn{2}{|c|}{$\begin{array}{l}\text { Baseline characteristics of patients included in } \\
\text { the study }\end{array}$} \\
\hline \multicolumn{2}{|c|}{ Sex males/females } & $588(70) / 254(30)$ \\
\hline \multicolumn{2}{|c|}{ Age yrs } & $68.4 \pm 12.2$ \\
\hline \multicolumn{2}{|l|}{$\mathrm{BMI} \mathbf{k g} \cdot \mathrm{m}^{-2}$} & $26.9 \pm 5.6$ \\
\hline \multicolumn{3}{|l|}{ Diagnosis } \\
\hline \multicolumn{2}{|l|}{ ILD } & $77(9.1)$ \\
\hline \multicolumn{2}{|l|}{ COPD } & $628(74.2)$ \\
\hline \multicolumn{2}{|c|}{ Vascular disease } & $43(5.1)$ \\
\hline \multicolumn{2}{|l|}{ Others } & 98 (11.6) \\
\hline \multicolumn{2}{|l|}{ pH } & $7.41 \pm 0.04$ \\
\hline \multicolumn{2}{|l|}{$\mathrm{Pa}, \mathrm{O}_{2} \mathrm{mmHg}$} & $58.4 \pm 10.0$ \\
\hline \multicolumn{2}{|l|}{$\mathrm{Pa}, \mathrm{CO}_{2} \mathrm{mmHg}$} & $45.3 \pm 8.0$ \\
\hline \multicolumn{2}{|c|}{ Bicarbonate $\mathrm{mmol} \cdot \mathrm{L}^{-1}$} & $28.5 \pm 3.7$ \\
\hline \multicolumn{2}{|l|}{$\mathrm{Sa}, \mathrm{O}_{2} \%$} & $88.6 \pm 5.7$ \\
\hline \multicolumn{2}{|l|}{$\mathrm{Sp}, \mathrm{O}_{2} \%$} & $89.1 \pm 5.3$ \\
\hline
\end{tabular}

Data are presented as $n(\%)$ or mean \pm SD. BMl: body mass index; ILD: interstitial lung disease; COPD: chronic obstructive pulmonary disease; $\mathrm{Pa}_{1} \mathrm{O}_{2}$ : arterial oxygen tension; $\mathrm{Pa}_{1} \mathrm{CO}_{2}$ : arterial carbon dioxide tension; $\mathrm{Sa}_{2} \mathrm{O}_{2}$ : arterial oxygen saturation; $\mathrm{Sp}, \mathrm{O}_{2}$ : arterial oxygen saturation measured by pulse oximetry. guidelines [17]. Briefly, samples were anaerobically drawn into 5-mL pre-heparinised syringes following administration of local anaesthesia in the area of the radial artery. Air bubbles were removed from the syringes and each sample was immediately taken for analysis. Arterial blood was analysed using an IL 682 co-oximeter (Instrumentation Laboratories, Lexington, MA, USA). $\mathrm{Sa}_{1} \mathrm{O}_{2}$ was determined with the following formula in which $\mathrm{FO} 2 \mathrm{Hb}$ is the oxyhaemoglobin fraction, $\mathrm{FCOHb}$ is the carboxyhaemoglobin fraction, and FmetHb is the methaemoglobin fraction.

$$
\mathrm{Sa}, \mathrm{O}_{2}=100 \times\left(\mathrm{FO}_{2} \mathrm{Hb} / 100\right)-(F \mathrm{COHb}+F \text { metHb })
$$

Carboxyhaemoglobin and methaemoglobin values were also systematically recorded in all the determinations carried out.

Measurement of arterial oxygen saturation by pulse oximetry Arterial oxygen saturation was measured with Minolta pulse oximeters (Pulsox-7; Minolta Company Ltd, Milton Keynes, UK). The measurement was taken with a digit sensor, and great care was taken to ensure that the test person's fingers were warm during the process. Measurements were performed when the subject was awake, had not exercised, and had been sitting for $\geqslant 10 \mathrm{~min}$ in the same position, and after an interval of $\geqslant 1.5 \mathrm{~h}$ since the last meal. It took $1-3 \mathrm{~min}$ for the measured $\mathrm{Sp}, \mathrm{O}_{2}$ value on the display to remain constant for $>15 \mathrm{~s}$. This value was taken as $\mathrm{Sp}_{\mathrm{p}} \mathrm{O}_{2}$ at rest. In some patients, particularly those with severe hypoxaemia, saturation never fully stabilised. In these cases, the investigator measured continuously for $\sim 2 \mathrm{~min}$, with all values being recorded in the pulse oximeter's memory. The minimum and maximum values were noted and the value appearing most frequently in the 2-min recording (i.e. the predominant value) was taken for the analysis, as has been described previously [18].

\section{Statistical analysis}

To investigate concordance between the two methods for estimating oxygen saturation, pulse oximetry and co-oximetry (the reference method), the mean of both methods was plotted against the difference (bias $=\mathrm{Sa}_{2} \mathrm{O}_{2}-\mathrm{Sp}, \mathrm{O}_{2}$ ), according to the Bland-Altman recommendations $[19,20]$. The Bland-Altman $95 \%$ limits of agreement (mean bias $\pm 2 \mathrm{SD}$ ) procedure uses datascale assessment to analyse the accuracy (i.e. bias) and the amount of variation, or precision, between any two measured values when the range of data is sufficiently limited.

Lin's concordance coefficient (LCC) and the corresponding $95 \%$ confidence interval were also used to determine the agreement between the two methods [21-23]. The LCC measures of both precision and accuracy to determine whether the observed data deviate significantly from the line of perfect concordance, which occurs at 45 degrees; that is, it assesses the linear relationship between two variables under the constraint that the intercept is zero and the slope is one. The value of LCC increases as the accuracy and precision of the observed data improve.

In order to evaluate the impact of arterial oxygen tension $\left(\mathrm{Pa}, \mathrm{O}_{2}\right)$ and $\mathrm{Pa}, \mathrm{CO}_{2}$ on the measurements obtained by the two methods, the determinations were categorised by tertiles. To assess the combined effect of both these variables, the cut-off points used were the median for $\mathrm{Pa}, \mathrm{O} 2$ and tertiles for $\mathrm{Pa}, \mathrm{CO}$, resulting in six groups being available for the analysis. 
Multivariate regression analysis was carried out to assess the repercussions of $\mathrm{pH}, \mathrm{Pa}_{2} \mathrm{O}_{2}, \mathrm{~Pa}_{1} \mathrm{CO}_{2}$, and bicarbonate on the bias. Standardised coefficients were used to rule out the adjusted influence of these variables concomitantly.

Significance was defined as a two-tailed p-value of $<0.05$.

\section{RESULTS}

The variables analysed are summarised in table 2. Cut-off values for $\mathrm{Pa}, \mathrm{O}_{2}$ and $\mathrm{Pa}, \mathrm{CO}_{2}$ were as follows: tertiles for $\mathrm{Pa}_{1} \mathrm{O}_{2}$ of $54 \mathrm{mmHg}(7.19 \mathrm{kPa})$ and $62 \mathrm{mmHg}(8.26 \mathrm{kPa})$; tertiles for $\mathrm{Pa}_{1} \mathrm{CO}_{2}$ of $41.9 \mathrm{mmHg}(5.59 \mathrm{kPa})$ and $48 \mathrm{mmHg}(6.40 \mathrm{kPa})$; and median $\mathrm{Pa}, \mathrm{O}_{2} 58 \mathrm{mmHg}(7.73 \mathrm{kPa})$. The differences between pulse oximetry and co-oximetry results plotted against the average of the two according to the grade of hypoxaemia (Bland-Altman method) are shown in figure 1.

Agreement between $\mathrm{Sa}_{2} \mathrm{O}_{2}$ and $\mathrm{Sp}_{\mathrm{p}} \mathrm{O}_{2}$ was poorer for lower values of $\mathrm{Pa}, \mathrm{O}_{2}$ and for higher values of $\mathrm{Pa}_{1} \mathrm{CO}_{2}$. The differences by $\mathrm{Pa}, \mathrm{CO}_{2}$ level are shown in figure 2: the degree of agreement becomes progressively lower as $\mathrm{Pa}_{1} \mathrm{CO}_{2}$ increases. Analysis of $\mathrm{Pa}_{1} \mathrm{O}_{2}$ and $\mathrm{Pa}, \mathrm{CO}_{2}$ values together disclosed poorer agreement in hypoxic patients with increased $\mathrm{Pa}_{1} \mathrm{CO}_{2}$ (table 2 and fig 3 ). The analysis performed using the LCC method estimated overall concordance at 0.91 , with the estimates ranging from 0.63 (second $\mathrm{Pa}_{\mathrm{a}} \mathrm{O}_{2}$ tertile) to 0.92 (first $\mathrm{PaCO}_{2}$ tertile).

The results of the adjusted multivariate analysis, performed to assess the impact of the different factors on the bias (table 3), indicate that $\mathrm{Pa}, \mathrm{O}_{2}, \mathrm{PaCO}_{2}$ and their interaction term were the most important predictors (standardised estimates of -0.54 -0.94 and 0.85 , respectively). The effect of $\mathrm{pH}$ was small, although statistically significant, and bicarbonate had no significant effect.

\section{DISCUSSION}

The main finding emerging from the present study is that $\mathrm{Pa}, \mathrm{CO}_{2}$ levels can affect the accuracy and reliability of $\mathrm{Sp}, \mathrm{O}_{2}$ measurements. Agreement between $\mathrm{Sa}_{\mathrm{a}} \mathrm{O}_{2}$ and $\mathrm{Sp}, \mathrm{O}_{2}$ decreases as $\mathrm{Pa}_{2}, \mathrm{CO}_{2}$ increases, regardless of the grade of associated hypoxaemia. Moreover, in a large series of determinations, the present study also confirmed that $\mathrm{Sp}, \mathrm{O}_{2}$ correlates poorly with $\mathrm{Sa}, \mathrm{O}_{2}$ when $\mathrm{Pa}, \mathrm{O}_{2}$ is low, particularly when it is $<54 \mathrm{mmHg}(7.20 \mathrm{kPa})$.

To the current authors knowledge, the possibility that alterations in blood carbon dioxide levels might affect concordance between $\mathrm{Sa}_{2} \mathrm{O}_{2}$ and $\mathrm{Sp}, \mathrm{O}_{2}$ measurements has not been specifically investigated. The only closely related study is by LEE et al. [8], who assessed the accuracy of pulse oximetry in 664 determinations in the emergency department. Following an analysis of several variables including age, sex and levels of haemoglobin, bicarbonate, $\mathrm{pH}, \mathrm{Pa}_{2} \mathrm{O}_{2}, \mathrm{~Pa}_{1} \mathrm{CO}_{2}$, and carboxyhaemoglobin, LEE et al. [8] concluded that the only variable affecting agreement between $\mathrm{Sa}_{2} \mathrm{O}_{2}$ and $\mathrm{Sp}, \mathrm{O}_{2}$ was carboxyhaemoglobin level. In the analysis, however, the authors categorised the oxygen saturation results of the two methods instead of performing direct assessment with LCC and the

TABLE 2 Bias, agreement and concordance for estimation of oxygen saturation comparing pulse oximeter and co-oximeter results

\begin{tabular}{|c|c|c|c|c|c|c|c|}
\hline & \multirow[t]{3}{*}{ Subjects } & \multicolumn{4}{|c|}{ Average versus mean difference ${ }^{\#}$} & \multicolumn{2}{|c|}{ LCC } \\
\hline & & \multirow[t]{2}{*}{ Bias $\left(\mathrm{Sa}, \mathrm{O}_{2}-\mathrm{Sp}, \mathrm{O}_{2}\right)$} & \multirow[t]{2}{*}{ Agreement $95 \% \mathrm{Cl}$} & \multicolumn{2}{|c|}{ Regression } & \multirow[t]{2}{*}{ Estimate } & \multirow[t]{2}{*}{$95 \% \mathrm{Cl}$} \\
\hline & & & & Intercept & Slope & & \\
\hline All & 846 & -0.47 & $-5.04-4.10$ & -8.84 & 0.09 & 0.91 & $0.90-0.92$ \\
\hline \multicolumn{8}{|c|}{ Tertiles of $\mathrm{Pa}_{3} \mathrm{O}_{2}{ }^{\circ}$} \\
\hline 1 st & 279 & -1.32 & $-7.78-5.15$ & -3.92 & 0.03 & 0.81 & $0.77-0.85$ \\
\hline 2nd & 274 & -0.34 & $-3.58-2.90$ & 5.91 & -0.07 & 0.63 & $0.55-0.70$ \\
\hline 3rd & 293 & 0.21 & $-2.36-2.77$ & 12.17 & -0.13 & 0.72 & $0.67-0.77$ \\
\hline \multicolumn{8}{|c|}{ Tertiles of $\mathrm{Pa}, \mathrm{CO}_{2}^{+}$} \\
\hline 1st & 283 & 0.08 & $-3.61-3.76$ & -6.06 & 0.07 & 0.92 & $0.90-0.94$ \\
\hline 2nd & 289 & -0.28 & $-4.13-3.57$ & -1.76 & 0.02 & 0.89 & $0.87-0.92$ \\
\hline 3rd & 274 & -1.24 & $-6.86-4.38$ & -8.48 & 0.08 & 0.88 & $0.85-0.90$ \\
\hline \multicolumn{8}{|c|}{ Median $\mathrm{Pa}, \mathrm{O}_{2}$ or less ${ }^{\S}$} \\
\hline $1 \mathrm{~T} \mathrm{~Pa}, \mathrm{CO}_{2}$ & 93 & -0.57 & $-5.26-4.13$ & -4.79 & 0.05 & 0.86 & $0.80-0.91$ \\
\hline $2 \mathrm{~T} P \mathrm{a}, \mathrm{CO}_{2}$ & 122 & -0.58 & $-5.65-4.50$ & 2.60 & -0.04 & 0.81 & $0.74-0.86$ \\
\hline 3Т $\mathrm{Pa}, \mathrm{CO}_{2}$ & 201 & -1.49 & $-7.77-4.78$ & -7.05 & 0.07 & 0.84 & $0.80-0.88$ \\
\hline \multicolumn{8}{|c|}{ Greater than Median } \\
\hline \multicolumn{8}{|c|}{$\mathrm{Pa}, \mathrm{O}_{2}^{\S}$} \\
\hline $1 \mathrm{~T} P \mathrm{a}, \mathrm{CO}_{2}$ & 190 & 0.40 & $-2.53-3.32$ & 18.31 & -0.19 & 0.73 & $0.66-0.79$ \\
\hline $2 \mathrm{~T} P \mathrm{a}, \mathrm{CO}_{2}$ & 167 & -0.06 & $-2.67-2.54$ & 9.29 & -0.10 & 0.78 & $0.71-0.83$ \\
\hline 3Т $\mathrm{Pa}, \mathrm{CO}_{2}$ & 73 & -0.55 & $-3.42-2.33$ & -6.70 & 0.07 & 0.68 & $0.53-0.78$ \\
\hline
\end{tabular}

$\mathrm{Cl}$ : confidence interval; $\mathrm{Sa}, \mathrm{O}_{2}$ : arterial oxygen saturation; $\mathrm{Sp}, \mathrm{O}_{2}$ : arterial oxygen saturation measured by pulse oximetry; $\mathrm{Pa}, \mathrm{O}_{2}$ : arterial oxygen tension; $\mathrm{Pa}, \mathrm{CO}_{2}$ : arterial carbon dioxide pressure; 1T: 1 st Tertile; $2 \mathrm{~T}: 2 \mathrm{nd}$ Tertile; $3 \mathrm{~T}: 3 \mathrm{rd}$ Tertile. ${ }^{*}$ : Blond-Altman approach; ${ }^{\bullet}$ : cutoff tertiles 54 and $62 \mathrm{mmHg}$; ${ }^{+}$: cutoff tertiles 49.9 and 48 mmHg;

§. cutoff median $58 \mathrm{mmHg}$. $1 \mathrm{mmHg}=0.133 \mathrm{kPa}$. 

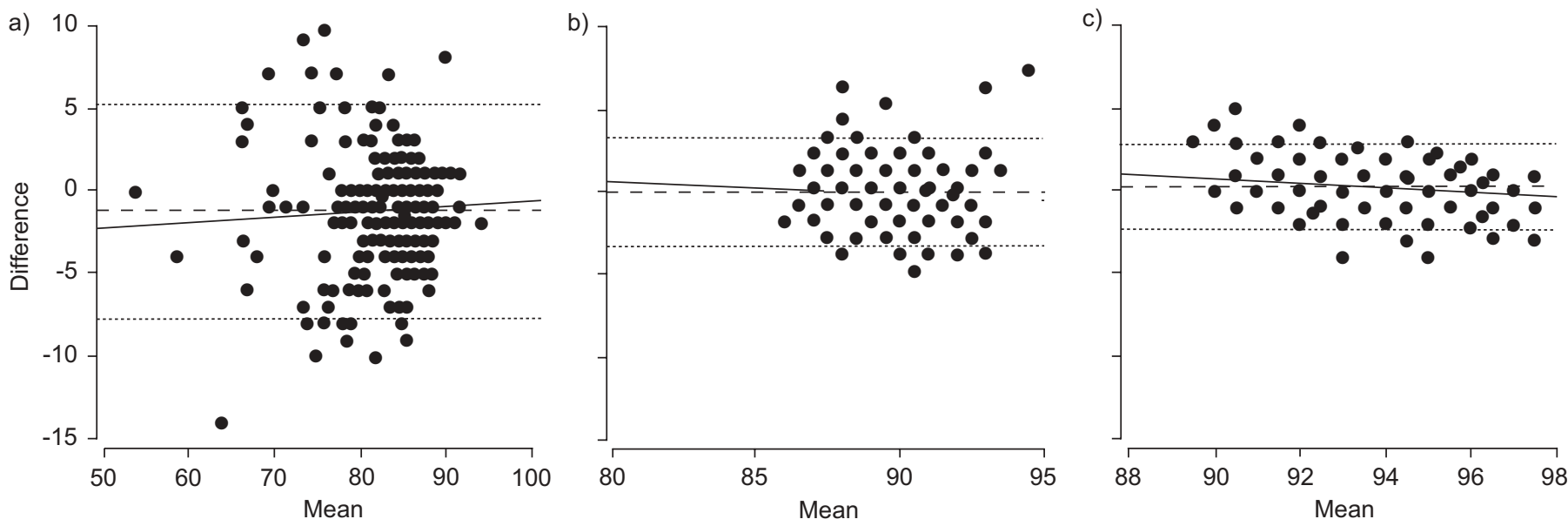

FIGURE 1. Difference versus mean of test and standard measurements, with mean bias (-----) $95 \%$ limits of agreements $(\cdot \cdots)$ and regression line $(\longrightarrow)$ by level of arterial oxygen tension, a) first tertile; b) second tertile; c) third tertile.

Bland-Altman approach, as was carried out in the present study. Moreover, including a variable in the analysis that is recognised as having an effect on $\mathrm{Sa}_{2} \mathrm{O}_{2}$ and $\mathrm{Sp}, \mathrm{O}_{2}$ agreement, namely carboxyhaemoglobin level [24], could have masked the effect of other variables, such as $\mathrm{Pa}_{\mathrm{a}} \mathrm{CO}_{2}$. In patients with normal carboxyhaemoglobin the present study found that, $\mathrm{Pa}, \mathrm{CO}_{2}$ levels can alter agreement between the two determinations and that the magnitude of this effect was greater for $\mathrm{Pa}_{\mathrm{a}} \mathrm{CO}_{2}$ than for $\mathrm{Pa}, \mathrm{O}_{2}$, the interaction between $\mathrm{Pa}, \mathrm{O}_{2}$ and $\mathrm{Pa}_{1} \mathrm{CO}_{2}$, bicarbonate, or $\mathrm{pH}$. It is also important to note that in the present study, $\mathrm{Sa}, \mathrm{O}_{2}$ measurements were adjusted for carboxyhaemoglobin and methaemoglobin; therefore, the results presented are likely to underestimate the overmeasurement bias occurring in the clinical setting, and may account for the apparently smaller bias seen here than in other comparisons.

The mechanism by which abnormal blood carbon dioxide levels can affect the agreement between $\mathrm{Sa}_{1} \mathrm{O}_{2}$ and $\mathrm{Sp}, \mathrm{O}_{2}$ measurements is unknown. Pulse oximetry provides instantaneous, in vivo determination of oxygen saturation by measuring arterial blood light absorption at two specific wavelengths, $660 \mathrm{~nm}$ (red) and
$940 \mathrm{~nm}$ (infrared), to distinguish between deoxygenated and oxygenated haemoglobin, whereas co-oximetry uses at least four different wavelengths of light for arterial blood gas analysis. In normal conditions, $\sim 5 \%$ of carbon dioxide in arterial blood and $30 \%$ in venous blood transported in a haemoglobin-bound form, as carbaminohaemoglobin [25]. It is reasonable to hypothesise that the presence of elevated $\mathrm{Pa}, \mathrm{CO}_{2}$ levels can alter the wavelength reading of the pulse oximeter because of increases in the amount of carbaminohaemoglobin, as occurs with carboxyhaemoglobin when carbon monoxide levels are elevated [24], or because of an increase in red blood cell osmolarity, which can induce changes in cell morphology [25]. Another possible explanation might be that the venous blood pulsatility index is larger in the context of a vasodilated dynamic circulation, owing to an increase in the $\mathrm{Pa}_{\mathrm{a}} \mathrm{CO}_{2}$.

The present findings indicate that the lack of agreement between $\mathrm{Sa}_{1} \mathrm{O}_{2}$ and $\mathrm{Sp}, \mathrm{O}_{2}$ in relation to carbon dioxide levels may be clinically relevant. The individuals studied were referred to the study centre to undergo assessment for home oxygen therapy. Some authors have proposed [11-13] that these patients can be
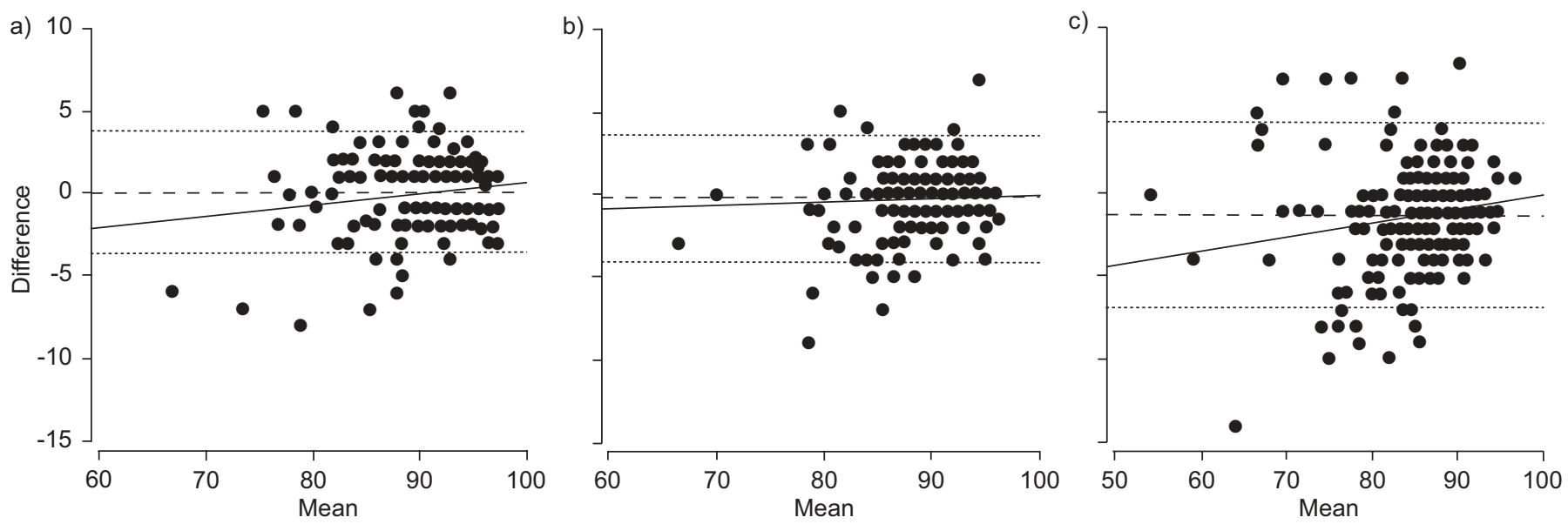

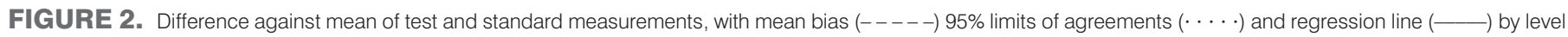
of arterial carbon dioxide pressure; a) first tertile; b) second tertile; c) third tertile. 

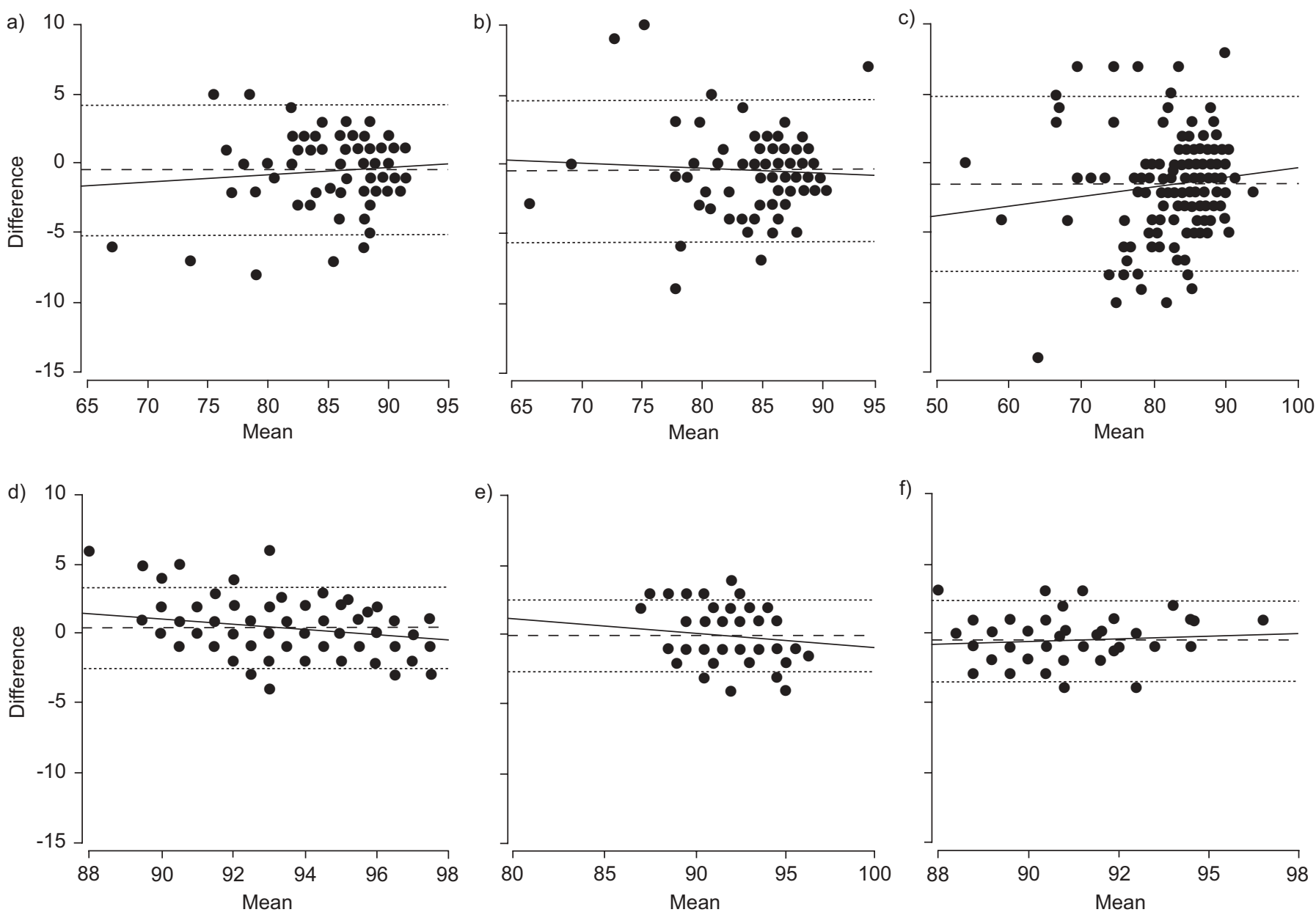

FIGURE 3. Difference versus mean of test and standard measurements, with mean bias (-- - - $), 95 \%$ limits of agreements $(\cdot \cdots)$ and regression line $(\longrightarrow)$ for levels of arterial oxygen tension $\left(\mathrm{Pa}_{2} \mathrm{O}_{2}\right)$ and arterial carbon dioxide pressure $\left(\mathrm{PaCO}_{2}\right)$ a) median or less $\mathrm{Pa}_{1} \mathrm{O}_{2}$ and first tertile of $\left.\mathrm{PaCO}_{2} ; \mathrm{b}\right)$ median or less $\mathrm{Pa}, \mathrm{O}_{2}$ and second tertile of $\mathrm{PaCO}_{2} ; \mathrm{C}$ ) median or less $\mathrm{Pa}_{1} \mathrm{O}_{2}$ and third tertile of $\mathrm{PaCO}_{2} ;$ d) more than the median $\mathrm{Pa}_{2} \mathrm{O}_{2}$ and first tertile of $\mathrm{PaCO}_{2} ;$ e) more than the median $\mathrm{Pa}_{2} \mathrm{O}_{2}$ and second tertile of $\mathrm{PaCO}_{2}$ f) more than the median $\mathrm{Pa}_{2} \mathrm{O}_{2}$ and third tertile of $\mathrm{PaCO}_{2}$.

evaluated by pulse oximetry alone, without the need for arterial blood gas analysis. Nevertheless, 59\% of the patients in the present study had high $\mathrm{Pa}, \mathrm{CO}_{2}$ levels, which we have shown can lead to overestimation of $\mathrm{Sa}_{2} \mathrm{O}_{2}$. On the basis of these results, the physician might not prescribe oxygen for these patients, or prescribe an inadequate flow.

TABLE 3 Multivariate regression to assess the influence of $\mathrm{pH}$, arterial oxygen tension $\left(\mathrm{Pa}, \mathrm{O}_{2}\right)$, carbon dioxide arterial tension $\left(\mathrm{Pa}, \mathrm{CO}_{2}\right)$ and bicarbonate on the oxygen saturation bias, i.e. difference between pulse oximeter and co-oximeter measurements (arterial oxygen saturation minus arterial oxygen saturation measured by pulse oximetry)

\begin{tabular}{|c|c|c|c|c|c|c|}
\hline & \multicolumn{2}{|c|}{ Univariate } & \multicolumn{2}{|c|}{ Multivariate $\mathrm{I}^{\#}$} & \multicolumn{2}{|c|}{ Multivariate II" } \\
\hline & Estimate $(95 \% \mathrm{Cl})$ & $\begin{array}{l}\text { Standard } \\
\text { Estimate }\end{array}$ & Estimate $(95 \% \mathrm{Cl})$ & $\begin{array}{l}\text { Standard } \\
\text { Estimate }\end{array}$ & Estimate $(95 \% \mathrm{Cl})$ & $\begin{array}{l}\text { Standaro } \\
\text { Estimate }\end{array}$ \\
\hline pH & $15.63(11.88-19.38)$ & 0.27 & $10.62(5.24-15.99)$ & 0.19 & $8.95(3.61-14.29)$ & 0.16 \\
\hline Bicarbonate $\mathrm{mmol} \cdot \mathrm{L}^{-1}$ & $-0.10(-0.14--0.05)$ & -0.15 & $0.00(-0.07-0.08)$ & 0.004 & $0.05(-0.03-0.12)$ & 0.07 \\
\hline $\mathrm{Pa}, \mathrm{O}_{2} \cdot \mathrm{Pa}, \mathrm{CO} 2$ & & & & & $0.004(0.002-0.006)$ & 0.85 \\
\hline
\end{tabular}

\#: only main effects were fitted in the multivariate I model. $~ ?$ : all main effects and the $P a, O_{2}$ by $P a, C_{2}$ interaction term were fitted in the multivariate II model. 
Another situation that is becoming increasingly more common in daily clinical practice is assessment of patients who might benefit from noninvasive home mechanical ventilation (NIHMV). Some authors have suggested that adaptation to NIHMV can be performed according to the response observed on pulse oximetry $[14,26]$. Considering that nearly all the patients who receive this treatment have high $\mathrm{Pa}_{1} \mathrm{CO}_{2}$ levels, the overestimation of $\mathrm{Sa}_{1} \mathrm{O}_{2}$ produced when there is severe hypercapnia might lead to a suboptimal choice of ventilation parameters.

In the present study patients with hypoxaemia, a decrease in $\mathrm{Pa}_{1} \mathrm{CO}_{2}$ to levels below the first tertile $\left(\mathrm{Pa}_{1} \mathrm{CO}_{2}<42 \mathrm{mmHg}\right.$ $(5.60 \mathrm{kPa})$ ) also affected agreement between $\mathrm{Sa}_{2} \mathrm{O}_{2}$ and $\mathrm{Sp}, \mathrm{O}_{2}$. Under these conditions, $\mathrm{Sp}, \mathrm{O}_{2}$ underestimates $\mathrm{Sa}_{\mathrm{a}} \mathrm{O}_{2}$, although the magnitude of the discrepancy is smaller than when $\mathrm{Pa}, \mathrm{CO}_{2}$ levels are elevated. This fact may be relevant in clinical situations of hyperventilation, as occurs in patients with pulmonary thromboembolism or pulmonary hypertension, or when assessing adaptation to hypobaric hypoxia in the process of acclimatisation to high altitudes [27-31].

The present study also showed that $\mathrm{Sp}_{\mathrm{p}} \mathrm{O}_{2}$ correlates poorly with $\mathrm{Sa}, \mathrm{O}_{2}$ when $\mathrm{Pa}, \mathrm{O}_{2}$ is low. These findings are similar to reported results demonstrating that most pulse oximeters are accurate to $\pm 4 \%$ in normal patients when $\mathrm{Sa}_{\mathrm{a}_{2}} \mathrm{O}_{2}$ is $>70 \%[6-7,32-34]$. The additional value of the present data is that it was obtained in a large number of determinations from patients with various respiratory pathologies attended on an outpatient basis. Moreover, in contrast to previous studies, it was possible to examine a large series of samples from patients with very low $\mathrm{Pa}_{\mathrm{a}} \mathrm{O}_{2}$, in whom agreement was particularly poor.

The present results were obtained in outpatients with stable respiratory disease. This fact might be considered a limitation of the study because the effect of acute $\mathrm{Pa}_{1} \mathrm{CO}_{2}$ changes in parallel with the $\mathrm{pH}$ were not evaluated. In this regard, some authors have suggested that acidosis might result in poorer agreement between $\mathrm{Sa}_{1} \mathrm{O}_{2}$ and $\mathrm{Sp}_{\mathrm{p}} \mathrm{O}_{2}$ [35], whereas a recent study did not confirm this possibility [36]. Moreover, $S p, \mathrm{O}_{2}$ is generally higher in the outpatient population than in intensive care patients and most hospitalised patients. In the hospital setting the effect of altered $\mathrm{Pa}, \mathrm{CO}_{2}$ and low $\mathrm{Sa}, \mathrm{O}_{2}$ may be more pronounced. Another limitation of the study is the fact that the pulse oximeters used were all the same model. Oximeters from different manufacturers show small differences related to the algorithms used to determine $\mathrm{Sp}, \mathrm{O}_{2}$ from the raw measurements of red and infrared light transmitted through the tissues. These differences were greater in the early days of oximetry than they are now because the current technical characteristics and performance of the majority of pulse oximeters are quite similar $[6,7,32-34,37]$ and all will be equally affected by the various factors known to alter the accuracy of $\mathrm{Sa}_{1} \mathrm{O}_{2}$ measurements. Although the effect of $\mathrm{Pa}, \mathrm{CO}_{2}$ on the accuracy of these devices has not been systematically assessed, it is likely that the present findings can be generalised to other models. Lastly, it cannot be excluded that elevated levels of $\mathrm{Pa}_{1} \mathrm{CO}_{2}$ might also affect the co-oximetry readings, although in the literature no data encountered support this idea.

In conclusion, in a heterogeneous group of patients with advanced respiratory disease, the present authors report that carbon dioxide arterial tension status can impair the agreement between arterial oxygen saturation and arterial oxygen saturation measured by pulse oximetry, particularly in patients with hypercapnia. In addition, the present results in a large number of paired samples show that agreement between arterial oxygen saturation and arterial oxygen saturation measure by pulse oximetry worsens as hypoxaemia values decrease. Therefore, it is likely that arterial oxygen saturation measured by oximetry may not be sufficiently accurate when assessing patients for long-term home oxygen therapy and should not substitute the gold standard arterial oxygen tension measured in arterial blood.

\section{REFERENCES}

1 Jubran A. Pulse oximetry. Intensive Care Med 2004; 30: 2017-2020.

2 Haynes JM. A case of disparity between pulse oximetry measurements and blood gas analysis values. Respir Care 2004; 49: 1059-1060.

3 American Association for Respiratory Care. AARC Clinical practice guidelines: pulse oximetry. Respir Care 1991; 36: 1406-1409.

4 Shapiro RS, Kacmarek RM. Monitoring of the mechanically ventilated patient. In: Marini JJ, Slutsky AS, eds. Physiological basis of ventilatory support. New York, Marcel Dekker, 1998; pp. 709-782.

5 Hurford WE, Kratz A. Case records of the Massachusetts General Hospital. Weekly clinopathological exercises. Case 23-2004: A 50-year-old woman with low oxygen saturation. N Engl J Med 2004; 351: 380-387.

6 Alexander CM, Teller LE, Gross JB. Principles of pulse oximetry: theoretical and practical considerations. Anesth Analg 1989; 68: 368-376.

7 Hanning CD, Alexander-Williams JM. Pulse oximetry: a practical review. BMJ 1995; 311: 367-370.

8 Lee WW, Mayberry K, Crapo R, Jensen RL. The accuracy of pulse oximetry in the emergency department. Am J Emerg Med 2000; 18: 427-431.

9 McGovern JP, Sasse SA, Stansbury DW, Causing LA, Light RW. Comparison of oxygen saturation by pulse oximetry and co-oximetry during exercise testing in patients with COPD. Chest 1996; 109: 1151-1155.

10 Hannhart B, Michalski H, Delorme N, Chapparo G, Polu JM. Reliability of six pulse oximeters in chronic obstructive pulmonary disease. Chest 1991; 99: 842-846.

11 Tarpy SP, Celli BR. Long-term oxygen therapy. $N$ Engl J Med 1995; 333: 710-714.

12 Carlin BW, Clausen JL, Ries Al. The use of cutaneous oximetry in the prescription of long-term oxygen therapy. Chest 1988; 94: 239-241.

13 Pierson DJ. Pulse oximetry versus arterial blood gas specimens in long-term oxygen therapy. Lung 1990; 168: Suppl., 782-788.

14 Muñoz X, Crespo A, Martí S, Torres F, Ferrer J, Morell F. Comparative study of two different modes of non-invasive home mechanical ventilation in chronic respiratory failure. Respir Med 2006; 100: 673-681.

15 Martí S, Muñoz X, Rios J, Morell F, Ferrer J. Body weight and comorbidity predict mortality in COPD patients treated with oxygen therapy. Eur Respir J 2006; 27: 689-696. 
16 Kolb JC, Ferran P, Norris SR, Smith D, Mester J. Validation of pulse oximetry during progressive normobaric hypoxia utilizing a portable chamber. Can J Appl Physiol 2004; 29: 3-15.

17 Rodriguez-Roisin R, Agustí A, Burgos F, et al. Normativa sobre gasometria arterial. Grupo de trabajo de la SEPAR para la práctica de la gasometria arterial. Ediciones Doyma S.A. Barcelona, 1987. Arch Bronconeumol 1998; 34: 142-153.

18 Tannheimer M, Thomas A, Gerngross H. Oxygen saturation course and altitude symptomatology during and expedition to broad peak (8047 m). Int J Sports Med 2002; 23: 329-335.

19 Bland JM, Altman DG. Statistical methods for assessing agreement between two methods of clinical measurement. Lancet 1986; 1: 307-310.

20 Bland JM, Altman, DG., Comparing methods of measurement: Why plotting difference against standard methods is misleading. Lancet 1995; 346: 1085-1087.

21 Lin LI. Assay validation using the concordance correlation coefficient. Biometrics 1992; 48: 599-604.

22 Lin LI. A concordance correlation coefficient to evaluate reproducibility. Biometrics 1989; 45: 255-268.

23 Lin LI. A note on the concordance correlation coefficient. Biometrics 2000; 56: 324-325.

24 Hampson NB. Pulse oximetry in severe carbon monoxide poisoning. Chest 1998; 114: 1036-1041.

25 West JB. Respiratory Physiology. 7th Edn., Buenos Aires, Médica Panamericana, 2005.

26 Mehta S, Hill NS. Non-invasive ventilation. Am J Respir Crit Care Med 2001; 163: 540-577.

27 Basnyat B, Lemaster J, Lictch J. Everest or bust: a cross sectional, epidemiological study of acute mountain sickness at 4243 meters in the Himalayas. Aviat Space Environ Med 1999; 70: 867-873.
28 Roach RC, Greene ER, Schoene RB, Hackett PH. Arterial oxygen saturation for prediction of acute mountain sickness. Aviat Space Environ Med 1998; 69: 1182-1185.

29 O'Connor T, Dubowitz G, Bickler PE. Pulse oximetry in the diagnosis of acute mountain sickness. High Alt Med Biol 2004; 5: 341-348.

30 Roach RC, Houston CS, Honigman B, et al. How well do older persons tolerate moderate altitude? West J Med 1995; 162: 32-36.

31 Roeggla G, Roeggla M, Podolsky A, Wagner A, Laggner AN. How can acute mountain sickness be quantified at moderate altitude. $J R$ Soc Med 1996; 89: 141-143.

32 Taylor MB, Whitwam JG. The accuracy of pulse oximeters: a comparative clinical evaluation of five pulse oximeters. Anaesthesia 1988; 43: 229-232.

33 Choe H, Tashiro C, Fukumitsu K, Yagi M, Yoshiya I. Comparison of recorded values from six pulse oximeters. Crit Care Med 1989; 17: 678-681.

34 Severinghaus JW, Naifeh KH, Koh SO. Errors in 14 pulse oximeters during profound hypoxia. J Clin Monit 1989; 5: 72-81.

35 Ralston AC, Webb RK, Runciman WB. Potential errors in pulse oximetry. I. Pulse oximeter evaluation. Anaesthesia 1991; 46: 202-206.

36 Perkins GD, McAuley DF, Giles S, Routledge H, Gao F. Do changes in pulse oximeter oxygen saturation predict equivalent changes in arterial oxygen saturation? Crit Care 2003; 7: R67-R71.

37 Trivedi NS, Ghouri AF, Lai E, Shah NK, Barker SJ. Pulse oximeter performance during desaturation: a comparison of seven models. J Clin Anesth 1997; 9: 184-188. 